\title{
WORLD HEALTH ORGANIZATION-FIVE WELL-BEING INDEX: AN APPRAISAL OF DISTRICTS OF KHYBER PAKHTUNKHWA, PAKISTAN
}

\section{Danish Wadud Alam', Amjad Amin ${ }^{\prime \otimes}$}

\begin{abstract}
OBJECTIVE: To evaluate the mental wellbeing of the general population in districts of Khyber Pakhtunkhwa (KP) province of Pakistan using the World Health Organization-Five (WHO-5) well-being index.

METHODS: WHO-5 well-being index questionnaire was used to document the mental well-being of individuals from thirteen most populous districts from seven divisional administrations of KP province. A rural-urban sample within these districts was estimated on the basis of proportional allocation method. The towns, villages and households in the selected districts were chosen through systematic random sampling technique by dividing the total households by the sample size. The mean score for the province was calculated and compared it to each district's scores and to the rural-urban scores.
\end{abstract}

RESULTS: Out of 500 households, 303 (60.6\%) were from rural and 197 (39.4\%) from urban areas. Mean WHO-5 wellbeing scores was $14.60 \pm 2.65$, $14.38 \pm 2.75 \& 14.81 \pm 3.13$ for province, urban and rural areas respectively. Higher scores reflecting better quality of life in various life domains was

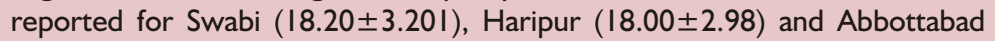

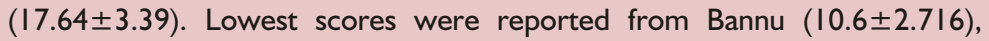
Charsadda $(11.5 \pm 2.89)$ \& Dera Ismail Khan $(12.03 \pm 3.25)$ districts. Higher score for urban areas was reported from Swabi (19.8 \pm 3.243$)$, Nowshehra (I7.77 \pm 3.10$)$ \& Haripur (I7.44 \pm 2.760 ), while for rural areas in Abbottabad

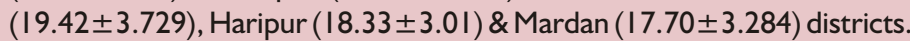

CONCLUSION: Mental well-being is higher for people living in Swabi, Haripur, \& Abbottabad and lower for residents of Bannu, Charsadda \& Dera Ismail Khan districts. Further research is required to study the contributing factors for lower mental well-being in these districts.

KEY WORDS: WHO-5 Well-Being Index (MeSH); Mental Health (MeSH); Wellbeing (MeSH); Khyber Pakhtunkhwa (MeSH).

THIS ARTICLE MAY BE CITED AS: Alam DW, Amin A. World Health Organization-Five Well-Being Index: an appraisal of districts of Khyber Pakhtunkhwa, Pakistan. Khyber Med Univ J 2021;13(I):20-24. DOI: https://doi.org//0.35845/kmuj.202I.20068

\section{INTRODUCTION}

Whescong

ell-being is a condition which holds meaning for individuals as well as society, as it shows their perception of living good lives. ${ }^{1-4}$ This good life is comprised of both material living conditions (e.g., housing, employment etc.) as well as subjective feelings like quality of relationships, positive emotions, satisfaction with life etc. ${ }^{5}$ It is also linked in matters of health to risk of disease, recovery and longevity. ${ }^{6-8}$

The World Health Organization-Five (WHO-5) well-being index is a concise self-reported measure of existing wellbeing. This measure was initially introduced by the World Health Organization/ Europe in 1998 as part of the DEPCARE Project on well-being which set out to introduce and use well-being measures in primary health care to identify and manage depression, psychological problems and stress related disorders focusing majorly on quality health care. It is a widely applied questionnaire with numerous language translations and found to be adequately valid in clinical trials as well as having adequate construct validity as a uni-dimensional measure gauging well-being.
I: Department of Economics, University of Peshawar, Peshawar, Pakistan Email四:amjadamin@uop.edu.pk Cell \# +92-333-9285505

Date Submitted: February 03, 2020

Date Revised: January 08, 2021

Date Accepted: February 09, 2021

The WHO- 5 has been tested for its validity and usefulness as an instrument for identifying depression. ${ }^{10}$ Other scales of mental well-being are also in use " however the ease and reliability of the WHO-5 is confirmed by researchers. ${ }^{12-14}$ The cost of disease studies also suggest that timely diagnosis can affect cure and treatment saving high financial costs to health care sectors. ${ }^{15,16}$

The significance of mental well-being in terms of improvement in quality of life and preventing illness has gained substantial ground. ${ }^{17}$ As the cost of mental illness rises, the need for more attention to the question of mental health in the national perspective arise. ${ }^{18}$ In Pakistan there exists no reliable estimate of the cost of mental illness at the public health care level where the government spends less than $1 \%$ of its gross domestic product (GDP) on the entire health sector and much less on mental health. ${ }^{19}$

Khyber Pakhtunkhwa (KP), the third largest province of the country on population basis and second poorest in terms of its contribution to the GDP, is also deficient in health care provision. ${ }^{20}$ Moreover the province of KP has undergone a substantial part of recent years through terrorism based insecurity among its population. Adding to it the demands of a fast-paced life exerts further pressures on its inhabitants. It is, therefore, pertinent to shed some light on their mental health. As there is no large scale study on wellbeing of people of KP, we planned this study to evaluate the mental well-being of the general population in thirteen districts of KP province of Pakistan. The present study has used the WHO-5 well-being instrument which has been previously used as an efficient and valid screen for 
psychological well-being in low income country.

\section{METHODS}

This cross sectional study was conducted in thirteen districts of Khyber Pakhtunkhwa, Pakistan in 201819. The target areas consisted of thirteen most populous districts of the province of Khyber Pakhtunkhwa. The selection of thirteen districts was done from all the seven divisional administrations of the province. Population was the basis of selection of the districts. The thirteen selected districts consist of more than seventy five percent of the total population of Khyber Pakhtunkhwa, which makes the selection an adequate sample for the purpose of this study (Bureau of Statistics, Islamabad, 201819). The selected districts are Peshawar, Mardan, Sawat, Mansehra, Sawabi, Charsadda, Dera Ismail Khan (D.I.K), Nowshehra, Lower Dir, Abbottabad, Bannu, Haripur, and Kohat.

The sample size selected for this study is 500 households, estimated by applying formula containing error of measurement $(5 \%)$, confidence interval and variance. The formula is given below; $\mathrm{Ns}^{2}$

$$
\mathrm{n}=\frac{}{(\mathrm{N}-\mathrm{I}) \mathrm{D}+\mathrm{s}^{2}}
$$

Where

$\mathrm{n}=$ Sample Size

$\mathrm{N}=$ Population Size

$s^{2}=$ Sample Variance $=\frac{(Y-\hat{Y})^{2}}{n-I}$
$D=B^{2} / 4$

$B=$ Bound on the error of estimation

Questionnaire was distributed by the researchers among the thirteen districts. The sample size was divided among the thirteen districts on the basis of population (given in table I below). Further a rural-urban sample within these districts was estimated on the basis of proportional allocation method. The towns and villages and the households in the selected districts were chosen through systematic random sampling technique by dividing the total households by the sample size.

The required data was collected from the households in the target areas through questionnaires. The questionnaires were directed towards head of the household. The unit of analysis was the household head. The household head is a person who has the authority to make important decisions of social and economic nature for the household.

The data was collected about the following WHO-5 aspects.

WHO-I: I have felt cheerful and in good spirits?

WHO-2: I have felt calm and relaxed?

WHO-3: I have felt active and vigorous?

WHO-4: I woke up feeling fresh and rested?

WHO-5: my daily life has been filled with things that interest me?

A Likert Scale of 0 to 5 is used for all these questions where;
$0=$ At no time

$\mathrm{I}=$ Some of the time

$2=$ Less than half of the time

$3=$ More than half of the time

$4=$ Most of the time

$5=$ All of the time

(The validated Urdu translation of the questionnaire was also used as and when required. $)^{22}$

As per WHO guidelines, the rough scores were estimated by summing Likert scale scores for all the five questions for a pre-determined range i.e. 0 to 5 . The maximum score is 25 and the minimum be zero. A " 0 " score shows the worst condition while " 25 " score shows the best condition of mental well-being. The raw score ( 0 to 25 ) is then multiplied by 4 to get a total score in the range of 0 to 100 . A " 0 " score shows the worst condition while "I00" score shows the best condition of mental well-being. The standard score for worst wellbeing as well as depression is a score of I 3 .

The data was analyzed using SPSS software and the results were tabulated and explained.

\section{RESULTS}

Out of 500 participants, 393 (78.6\%) were males and 107 (2I.4\%) were females. Majority $(n=207 ; 41.4 \%)$ of study participants were aging less than 35 years, 257 (51.4\%) were in 35-54 years age group and 36 (7.2\%) were aging 55 years or above. Overall, 293 $(58.6 \%)$ were from rural areas and 207

TABLE I: DISTRICT WISE DISTRIBUTION OF SAMPLE SIZE

\begin{tabular}{|l|c|c|c|c|c|c|}
\hline \multirow{2}{*}{ District } & \multicolumn{2}{|c|}{ Rural (Households) } & \multicolumn{2}{c|}{ Urban (Households) } & \multicolumn{2}{c|}{ Total (Households) } \\
\cline { 2 - 7 } & $\begin{array}{c}\text { Population } \\
\text { size }\end{array}$ & $\begin{array}{c}\text { Sample } \\
\text { size }\end{array}$ & Population size & $\begin{array}{c}\text { Sample } \\
\text { size }\end{array}$ & $\begin{array}{c}\text { Population size } \\
\text { Sample } \\
\text { size }\end{array}$ \\
\hline Peshawar & 1,736 & 44 & 1,540 & 39 & 3,276 & 83 \\
\hline Mardan & 1,730 & 34 & 470 & 22 & 2,201 & 56 \\
\hline Swat & 1,687 & 32 & 302 & 18 & 1,989 & 50 \\
\hline Mansehra & 1,509 & 25 & 92 & 15 & 1,600 & 40 \\
\hline Sawabi & 1,257 & 22 & 280 & 17 & 1,537 & 39 \\
\hline Charsadda & 1,252 & 25 & 263 & 13 & 1,514 & 38 \\
\hline Dera Ismail Khan & 1,167 & 20 & 163 & 13 & 1,329 & 33 \\
\hline Nowshehra & 982 & 20 & 316 & 13 & 1,299 & 33 \\
\hline Lower Dir & 1,072 & 18 & 70 & 11 & 1,143 & 29 \\
\hline Abbottabad & 896 & 18 & 235 & 10 & 1,130 & 28 \\
\hline Bannu & 940 & 16 & 52 & 9 & 991 & 25 \\
\hline Haripur & 819 & 15 & 115 & 9 & 934 & 24 \\
\hline Kohat & 638 & 14 & 237 & 8 & 855 & 22 \\
\hline Total & & 303 & & 197 & & 500 \\
\hline
\end{tabular}


WORLD HEALTH ORGANIZATION-FIVE WELL-BEING INDEX:AN APPRAISAL OF DISTRICTS OF KHYBER PAKHTUNKHWA, PAKISTAN

TABLE II: WHO-5 WELLBEING SCORES OF DISTRICTS OF KHYBER PAKHTUNKHWA, PAKISTAN

\begin{tabular}{|c|c|c|c|}
\hline \multirow[t]{2}{*}{ DISTRICT } & \multicolumn{3}{|c|}{$\begin{array}{c}\text { WHO-5 WELLBEING RAW SCORE (RANGE } 0 \\
\text { TO 25) }\end{array}$} \\
\hline & Urban & Rural & Combine \\
\hline Swabi & $19.8 \pm 3.243$ & $17.20 \pm 3.108$ & $|8.20 \pm 3.20|$ \\
\hline Haripur & $17.44 \pm 2.760$ & $18.33 \pm 3.012$ & $18.00 \pm 2.983$ \\
\hline Abbottabad & $15.5 \pm 2.438$ & $19.42 \pm 3.729$ & $\mid 7.64 \pm 3.391$ \\
\hline Nowshehra & $17.77 \pm 3.107$ & $16.16 \pm 2.473$ & $16.56 \pm 3.004$ \\
\hline Mardan & $15.08 \pm 2.365$ & $17.70 \pm 3.284$ & $16.53 \pm 2.849$ \\
\hline Peshawar & $14.2 \pm 3.829$ & $16.14 \pm 3.859$ & $15.20 \pm 3.832$ \\
\hline Swat & $14.63 \pm 2.137$ & $15.53 \pm 3.590$ & $15.14 \pm 3.192$ \\
\hline Kohat & $12.5 \pm 3.337$ & $13.78 \pm 2.983$ & $|3.3| \pm 3.22 \mid$ \\
\hline Lower Dir & $10.35 \pm 2.573$ & $14.70 \pm 2.586$ & $|2.89 \pm 2.57|$ \\
\hline Mansehra & $12.06 \pm 2.564$ & $12.32 \pm 3.294$ & $12.22 \pm 2.994$ \\
\hline Dera Ismail Khan & $13.76 \pm 3.25 \mid$ & $10.9 \pm 3.255$ & $12.03 \pm 3.253$ \\
\hline Charsadda & $12.85 \pm 3.245$ & $10.70 \pm 2.117$ & $11.5 \pm 2.894$ \\
\hline Bannu & $11 \pm 2.801$ & $9.66 \pm 2.391$ & $10.6 \pm 2.716$ \\
\hline Khyber Pakhtunkhwa Province & $14.38 \pm 2.75$ & $14.81 \pm 3.13$ & $14.60 \pm 2.65$ \\
\hline
\end{tabular}

(4I.4\%) were from urban areas. Two hundred and ninety-eight (59.6\%) respondents were married and 202 (40.4\%) were unmarried. Out of 293 participants from rural areas, 169 (57.7\%) were married and I 24 (42.3\%) were unmarried. Among 207 participants from urban areas, 129 $(62.3 \%)$ were married and $78(37.7 \%)$ were unmarried. Thirty six (7.2\%) respondents had no formal education, 57 (II.4\%) had primary education, 126 $(25.2 \%)$ had secondary education and $28 \mathrm{I}(56.2 \%)$ had higher education. Employment status of the respondents showed 160 (32\%) had permanent employment, I 48 (29.6\%) had fixed/ contract employment and 192 (38.4\%) had an employment status other than permanent and contract status.

\section{Wellbeing Ranking of the Districts}

Overall mean WHO-5 well-being scores for Khyber Pakhtunkhwa province was $14.60 \pm 2.65$ and was $14.38 \pm 2.75$ \& $14.81 \pm 3.13$ for urban and rural areas respectively (Table II). Higher scores reflecting better quality of life in various life domains was reported for Swabi

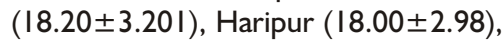
Abbottabad (17.64 13.39$)$ \& Nowshehra (17.64 \pm 3.39$)$. Lowest scores were reported from Bannu $(10.6 \pm 2.716)$ \& Charsadda (I $1.5 \pm 2.89)$ districts. Higher score for urban areas was reported from Swabi (19.8 \pm 3.243$)$ and Nowshehra (17.77 \pm 3.10$)$, while for rural areas in Abbottabad (19.42 \pm 3.729$)$ and Haripur (I8.33 $\pm 3.0 \mathrm{I})$ districts (Table II).
The raw scores of each respondent are then multiplied by 4 to give the final score, with 0 representing the worst well-being and 100 representing the best possible well-being. A person having less than 50 will be considered as having less mental wellbeing or at a risk of depression.

Overall score of WHO-5 well-being scale was 72.82, 72, $70.56 \& 66.24$ for Swabi, Haripur, Abbottabad \& Nowshehra districts respectively. Mansehra (48.88), Dera Ismail Khan (48.12), Charsadda (46.00) \& Bannu (42.40) had less than 50 score showing lower mental well-being (Table III).

\section{DISCUSSION}

In our study, the mean WHO-5 wellbeing scores for Khyber Pahunkhwa province was 14.60 2.65 and mean score for urban and rural areas was $14.38 \pm 2.75$ \& $\mid 4.81 \pm 3.13$ respectively. Higher scores reflecting better quality of life in various life domains was reported for Swabi, Haripur, Abbottabad \& Nowshehra. Lowest scores were reported from Bannu, Charsadda \& Dera Ismail Khan districts.

The study findings reflect that big cities of Khyber Pakhtunkhwa like Peshawar, Mardan, Dera Ismail Khan and Kohat have relatively less well-being as compared to cities like Swabi and Haripur. Abbotabad is a big city with good well-being. Districts with large well-developed centers have greater well-being experienced among its residents; however most of them reside in the rural areas of the districts. Similar study was conducted by Waqas, et. al; (20I5). ${ }^{23}$ They also found that people living in rural areas are happier than people living in urban areas. These rural areas are mostly peri-urban having relatively less pollution and more open spaces and fair access to urban amenities like transport, health \& sanitation and education facilities. The results are in accordance with Pressman SD et al. ${ }^{6}$ \& Ostir GV, et al.

In our study, the lowest scores was reported in Bannu, Charsadda, Dera Ismail Khan, Mansehra and Lower Dir. Majority of people living in these districts have lower socio-economic status and lower employment. Khan Y, et al; showed socio-demographic factors association with psychological well-being in young adolescents of Gilgit Pakistan. $^{24}$ In developing countries like Pakistan, poor economic status is significantly associated with poor wellbeing and higher risk of depression and anxiety symptoms. ${ }^{25}$ Similarly, Jibeen T, et al; reported that demographic variables are associated with negative mental health outcome in Pakistani immigrants. ${ }^{26}$

The findings of the study highlight the importance of a much neglected area of mental well-being of the people living in various districts of Khyber Pakhtunkhwa province of Pakistan. These areas have been adversely affected by decade's long war on terror and previously the adverse effects of terror on psychological well-being has been documented in people living in Khyber Pakhtunkhwa. ${ }^{27}$ Our study highlights the magnitude of the problem of lower mental well-being in various districts. These baseline findings can be utilized by the policy makers for future planning and research in improving the mental well-being of common people living in these areas. Moreover, it emphasizes the use of WHO-5 well-being index at the primary care level by health care providers for screening the population for mental well-being and further evaluation for psychiatric illnesses accordingly.

\section{LIMITATIONS}

This study was mainly focused on the magnitude of mental well-being of the general population of Khyber 
TABLE III: WHO-5 WELLBEING SCORES OF DISTRICTS OF KHYBER PAKHTUNKHWA, PAKISTAN

\begin{tabular}{|l|c|c|c|}
\hline \multirow{2}{*}{ District } & \multicolumn{3}{|c|}{ WHO-5 WELLBEING RANKING SCORE } \\
& \multicolumn{3}{|c|}{ (RANGE 0 TO 100) } \\
\cline { 2 - 4 } & Urban & Rural & Combine \\
\hline Swabi & 79.2 & 68.83 & 72.82 \\
\hline Haripur & 69.77 & 73.33 & 72.00 \\
\hline Abbottabad & 62 & 77.7 & 70.56 \\
\hline Nowshehra & 71.11 & 64.66 & 66.24 \\
\hline Mardan & 60.32 & 70.83 & 66.14 \\
\hline Peshawar & 56.8 & 64.56 & 60.82 \\
\hline Swat & 58.545 & 62.142 & 60.56 \\
\hline Kohat & 50 & 55.14 & 53.24 \\
\hline Lower Dir & $4 I .4$ & 58.83 & 51.56 \\
\hline Mansehra & 48.26 & 49.28 & 48.88 \\
\hline Dera Ismail Khan & 55.07 & 43.6 & 48.12 \\
\hline Charsadda & 51.42 & 42.83 & 46.00 \\
\hline Bannu & 44 & 38.66 & 42.40 \\
\hline
\end{tabular}

Pakhtunkhwa and could not explore the underlying factors contributing for the low or high well-being among people living in various districts.

\section{CONCLUSIONS}

Mental well-being is higher for people living in Swabi, Haripur, \& Abbottabad districts and is lower for residents of Bannu, Charsadda \& Dera Ismail Khan districts of Khyber Pakhtunkhwa province of Pakistan. Urbanization, socioeconomic factors and living standard of the people could be responsible for variable mental wellbeing of various districts. Further research is required to study the contributing factors for lower mental well-being in these districts.

\section{REFERENCES}

I. Diener E. Subjective well-being. Psychol Bull I 984; 95:542-75.

2. Diener E, Oishi S. Money and happiness: Income and subjective well-being across nations. In: Diener E, Suh EM, editors. Culture and Subjective Well-being. The MIT press; 2003.p. 185-218.

3. Diener E, Scollon CN, Lucas RE. The evolving concept of subjective well-being: The multifaceted nature of happiness. In: Diener E, editor. Assessing well-being: The collected works of Ed Diener. New York: Springer; 2009. p. 67-100.

4. Frey BS, Stutzer A. Happiness and
Economics. New Jersey. Princeton University press; 2002:

5. Lyubomirsky S, King L, Diener E. The benefits of frequent positive affect: does happiness lead to success? Psychol Bull 2005; I3I(6): 803-55.

6. Pressman SD, Cohen S. Does positive affect influence health? Psycho Bull 2005; I 3 1:925-71 .

7. Ostir GV, Markides KS, Peek MK, Goodwin GS. The association between emotional well-being and the incidence of stroke in older adults. Psychosom Med 200 I;63(2): 2I0-15. DOI: https://doi.org/ 10.1097/00006842-20010300000003.

8. Fredrickson BL, Levenson RW. Positive emotions speed recovery from the cardiovascular sequelae of negative emotions. Cogn Emot | 998; | 2(2): | 9 | -220. DOI: https://doi.org/10.1080/026999398 $3797 / 8$.

9. Topp CW, Ostergaard SD, Sondergaard S, Bech P. The WHO-5 Wellbeing Index: A systematic review of literature. Psychother Psychosom 2015;84(3):167-76. DOI: https:// doi.org/I0. II 59/000376585.

10. Lopez MA, Gabilondo A, Codony M, García-Forero C, Vilagut G, Castellví P. Adaptation into Spanish of the Warwick-Edinburgh Mental Well-being Scale (WBMWBS) and preliminary validation in a student sample. Qual Life Res 2013; 22(5): I099-I04. DOI: https://doi.org/ |0.1007/s | | |36-0|2-0238-z.

II. Effertz T, Mann K. The burden of cost of disorders of the brain in Europe, the inclusion of harmful alcohol use and nicotine addiction. Eur Neuropsychopharmacol 2013; 23(7):742-8. DOI: https://doi.org/ 10.1016/j.euroneuro.2012.07.010.

12. Government of Pakistan Finance Division, Economic Advisor's Wing. Pakistan Economic Survey 20 I 8- 19. [Accessed on: February 0I, 2020]. Available from URL: https//www.finance.gov.pk.

13. Government of Pakistan Federal Bureau of Statistics. [Accessed on: February 0I, 2020]. Available from URL: http://www.pbs.gov.pk/

14. Heun R, Bonsignore M, Bakow K, Heun R. Validity of five-item WHO Well-being Index (WHO-5) in an elderly population. Eur Arc Psychiatry Clin Neurosci 200 I; 25I (Supp 2):27-31. DOI: https:// doi.org/10.1007/BF03035 I 23.

15. Santos JJA, Costa TA, Guilherme JH, da Silva WC, Abentroth LRL, Krebs JA. Adaptation and cross-cultural validation of Brazilian version of Warwick-Edinburgh mental wellbeing scale. Rev Assoc Med Bras (I992) 2015;6I(3):209-14. DOI: https://doi.org/10.1590/18069282.61.03.209.

16. Barua A, Kar N, Acharya D, Nagaraj K, Bhat HV, Nair NS. Validity of WHO-5 Well-being Index for screening of depression in an elderly Indian population. J Gerontol 2010;24: I 78-86.

17. Mortazavi F, Mousavi SA, Chaman R, Khosravi A. Validation of the World Health Organization-5 Well-Being Index; assessment of maternal wellbeing and its associated factors. Turk Psikiyatri Derg 20 I 5;26(I):48-55.

18. Gustavsson A, Svensson M, Jacobi F, Allgulanderd C, Alonsoe J, Beghi E. Corrigendum to "Cost of disorders of the brain in Europe 2010". Eur Neuropsychopharmacol 2011;22 (3):237-38. DOI: https://doi.org/ I0.1016/j.euroneuro.20I2.0I.00I. 
19. Sobocki P, Johnsson B, Angst J, Rehnberg C. Cost of depression in Europe. J Ment Health Policy Econ 2006;9(2): 87-98.

20. Wittchen HU, Jacob F, Rehm J, Gustavsson A, Svensson M, Jönsson $B$. The size and burden of mental disorders and other disorders of the brain in Europe. Eur Neuropsychopharmacol 20II;2I(9):65579. DOI: https://doi.org/10.1016/ j.euroneuro.2011.07.018.

21. Garland AF, Deyessa N, Desta M, Alem A, Zerihun T, Hall KG. Use of the WHO-5 perceived Well-being Index (WHO-5) as an efficient and potentially valid screen for depression in low income country. Fam Sys Health 20I8;36(2): I 48-58. DOI: https://doi.org//0.1037/ fsh0000344.
22. Bech P. Clinical Psychometrics, Wiley-Blackwell, Oxford, 2012.

23. Waqas A, Ahmad W, Haddad M, Taggart FM, Muhammad Z, Bukhari $\mathrm{MH}$. A psychometric evaluation of the Warwick-Edinburgh Mental Well-being Scale in a Pakistani population. Peer J 2015 Oct I;3:el264. DOI: https://doi.org/ 10.77|7/peerj. 1264.

24. Khan Y, Taghdisi MH, Nourijeylyani K. Psychological Well-being (PWB) of school adolescents aged I2-18 yr, its correlation with general levels of physical activity (PA) and social demographic factors in Gilgit Baltistan. Iran J Public Health 2015; 44(6):804- I3.

25. Khalid A, Qadir F, Chan SWY, Schwannauer M. Adolescents' mental health and well-being in developing countries: a crosssectional survey from Pakistan. J Ment Health 2019 Aug;28(4):389396. DOI: https://doi.org//0.1080/ 09638237.2018.1521919. Epub 2018 Nov 19.

26. Jibeen T, Khalid R. Predictors of psychological well-being of Pakistani immigrants in Toronto, Canada. Int J Intercult Relat 2010 Sep I;34(5):452-64. DOI: https://doi.org/10.1016/j.ijintrel.20 10.04.010

27. Shah SAA, Yezhuang T, Shah AM, Durrani DK, Shah SJ. Fear of Terror and Psychological Well-Being: The Moderating Role of Emotional Intelligence. Int J Environ Res Public Health. 2018 Nov 14; I5(I I):2554. DOI: https://doi.org/l0.3390/ ijerph I5I I 2554 .

\section{AUTHOR'S CONTRIBUTION}

Following authors have made substantial contributions to the manuscript as under:

DWA: Conception \& study design, analysis and interpretation of data, drafting the manuscript, final approval of the version to be published

AA: Acquisition of data, drafting the manuscript, final approval of the version to be published

Authors agree to be accountable for all aspects of the work in ensuring that questions related to the accuracy or integrity of any part of the work are appropriately investigated and resolved.

CONFLICT OF INTEREST
Authors declared no conflict of interest
GRANT SUPPORT AND FINANCIAL DISCLOSURE
Authors have declared no specific grant for this research from any
funding agency in the public, commercial or not-for-profit sectors

\section{CONFLICT OF INTEREST}

funding agency in the public, commercial or not-for-profit sectors

\section{DATA SHARING STATEMENT}

The data that support the findings of this study are available from the corresponding author upon reasonable request.

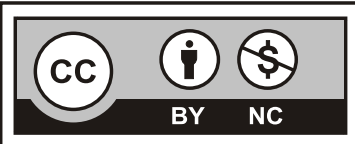

This is an Open Access article distributed under the terms of the Creative Commons Attribution-Non Commercial 2.0 Generic License.
KMUJ web address: www.kmuj.kmu.edu.pk

Email address: kmuj@kmu.edu.pk 